\title{
PERMASALAHAN LOKASI PEDAGANG KAKI LIMA (PKL) DALAM RUANG PERKOTAAN
}

\author{
Location Problem of Street Vendors in Urban Space
}

\section{Retno Widjajanti ${ }^{1}$}

\author{
Diterima : 31 Januari 2013 Disetujui : 18 September 2013
}

\begin{abstract}
Abstrak : Pembangunan perkotaan tidak terlepas dari masalah informal perkotaan. Sektor informal merupakan sektor yang akan selalu tumbuh dan berkembang. Berbagai permasalahan yang timbul dalam pembangunan diperkotaan adalah permasalahan lokasi ruang aktivitas pedagang kaki lima (PKL) di ruang perkotaan. Masalah ruang aktivitas PKL informal ini terjadi pada ruang permukiman atau ruang perkotaan. PKL merupakan salah satu aktivitas pendukung di ruang publik yang dapat dikategorikan sebagai 'activity support'. Aktivitas ini cenderung berlokasi di suatu tempat sesuai dengan aktivitasnya. Sementara itu, masih sedikit pembahasan PKL dalam pandangan ruang perkotaan. Hingga saat ini, pembahasan lebih kepada bidang ekonomi, sosial dan kebijakan. Selain itu, banyak dikaji dari sisi jenis aktivitas, kebutuhan ruang, penataan fisik dan penataan tampilan/estetika arsitektural. Metodologi yang digunakan dalam melakukan kajian permasalahan lokasi PKL dalam dalam ruang perkotaan menggunakan metode literatur review. Dengan adanya metode ini, dapat menemukenali kekurangan/kelemahan teori sektor informal dan teori ruang terhadap penentuan lokasi PKL di ruang perkotaan. Kesimpulan dari hasil penelitian ini ialah untuk mengetahui perilaku ruang PKL yang mempengaruhi penentuan lokasi berdagang.
\end{abstract}

\section{Kata kunci: PKL, lokasi, retail}

\begin{abstract}
Urban development is inseparable from the problem of the urban informal. The informal sector is a sector that will always grow and thrive. Various issues that arise in urban development is the problem of the location of the activity space street vendors (PKL) in the urban space. The problem of space activity occurs in the informal street vendors space settlements or urban space. PKL is one of the supporters of the activity in a public space that can be categorized as an 'activity support'. These activities tend to be located in a place according to its activity. Meanwhile, there is little discussion of urban street vendors in view space. Until now, the discussion is more to the economic, social and policy. In addition, many of the types of activities studied, space requirements, physical arrangement and the arrangement of the display / architectural aesthetics. The methodology used in conducting the study concerns the location of street vendors in the urban space using the method of literature revie. Given this method, can identify deficiencies / weaknesses of the informal sector theory and the theory of space to determine the location of street vendors in urban spaces. The conclusion of this research is to study the behavior of PKL space that affect the determination of the location of trade.
\end{abstract}

Keywords: street vendors, location, retail

\section{Latar Belakang}

Dalam global report on human settlement 2009, dijelaskan bahwa dalam pembangunan perkotaan masa kini, unsustainable for development tidak terlepas pada masalah informal

\footnotetext{
${ }^{1}$ Mahasiswa Program Doktor Perencanaan Wilayah dan Kota, SAPPK - ITB, Bandung

Staf Pengajar Jurusan Teknik Perencanaan Wilayah dan Kota, Fakultas Teknik, Universitas Diponegoro
} 
perkotaan. Masalah informal ini terjadi pada ruang permukiman atau ruang perkotaan, antara lain dalam bentuk informal perumahan, ekonomi perkotaan, dan fasilitas pelayanan. Informal dalam perumahan terdapat pada lahan yang belum terbangun/daerah untuk pembangunan yang akan datang, lahan tidak layak bangun, lahan konservasi lingkungan (bantaran sungai, dll). Informal perumahan ini terjadi karena untuk mengakomodasi kebutuhan tempat tinggal akibat pertumbuhan populasi penduduk perkotaan. Sedangkan informal dalam ekonomi khususnya usaha perkotaan atau Hart (1977) dan de Soto (1992) menyebutkan usaha kecil. Usaha kecil atau usaha perkotaan ini sebagai katup penyelamat dari sudut penciptaan lapangan kerja yang merupakan kegiatan memberi harapan untuk mencari penghidupan (de Soto, 1992). Kegiatan usaha kecil ini berada pada ruang publik dan tepi jalan (de Soto, 1992; Habitat, 2009).

Sektor informal merupakan salah satu sumber penghidupan penting di perkotaan, baik di negara berkembang maupun negara maju. Fakta menunjukkan bahwa di negara maju seperti di Inggris, Amerika Serikat, dan Spanyol, satu dari lima penduduk bekerja di sektor informal (Chandrakirana, 1994). Di negara-negara berkembang di Amerika Latin, Sub-Sahara Afrika, Timur Tengah, Afrika Utara, dan Asia Selatan proporsi tenaga kerja yang bekerja di sektor informal berkisar antara 30 - $70 \%$ dari total tenaga kerja bekerja. (Todaro, 2000; Santoso, 2009). Di Indonesia sendiri, diperkirakan $62 \%$ dari total tenaga kerja, bekerja di sektor informal (ILO-URDI, 2005). Besarnya kontribusi sektor informal terhadap perekonomian kota dan penciptaan kesempatan kerja menegaskan peran penting sektor ini dalam mengatasi masalah pengangguran dan menjadi katup pengaman perekonomian kota (de Soto, 1992; Rachbini, 1994). Namun ironisnya, keberadaan sektor informal belum dapat diterima oleh para pemegang kebijakan. Sering sektor informal selalu dianggap menimbulkan masalah di perkotaan. Terkait dengan pengakuan dan perlakuan yang saling bertolak belakang ini, sektor informal masih menjadi topik menarik untuk dikaji lebih lanjut, karena kajian mengenai tumbuh dan berkembang sektor informal sampai kapanpun akan terus ada dalam pembangunan, selama sektor formal tidak dapat menyediakan lapangan pekerjaan bagi usia kerja. Masalah sektor informal akan selesai jika ada cara keajaiban/kemujizatan untuk memecahkan ketersediaan lapangan kerja di sektor formal. Jadi selama sempitnya ketersediaan lapangan pekerjaan di sektor formal, maka masalah sektor informal tidak akan berhenti (Todaro, 2000). ILO sendiri, menekankan kepada negara-negara berkembang untuk bersikap lunak terhadap sektor informal, karena secara jelas dan nyata sektor ini sangat membantu untuk penyediaan lapangan pekerjaan selain di sektor formal. Pemerintah dihimbau untuk bersikap bijaksana dalam menangani masalah sektor informal, untuk mau menerima dan mewadahi aktivitas di ruang kota (ILO dalam Todaro, 2000). Namun pembahasan sektor informal yang sampai saat ini masih terus menjadi topik kajian adalah pedagang kaki lima (street vendors). Jenis-jenis kegiatan ekonomi yang masuk dalam kategori sektor informal sangat beragam, mulai dari perdagangan, transportasi, industri, dan jasa. Di dalam kategori perdagangan informal ini, terdapat kelompok pedagang kaki lima (Hart, 1973). Khususnya keberadaan PKL di ruang-ruang perkotaan sering dianggap sebagai masalah, dianggap mengganggu ketertiban, keamanan, kenyaman, kebersihan, dan keindahan lingkungan (de Soto, 1992; Firdausy, 1995; ILO-URDI, 2005). Padahal PKL ini berperan penting pula dalam penyediaan lapangan pekerjaan dan dapat menyediakan barang dan jasa yang mudah didapat dan terjangkau untuk kebutuhan sejumlah besar penduduk perkotaan. Perannya dalam penyediaan lapangan pekerjaan, seperti contoh di Indonesia 93\% dari total pekerjaan di sektor informal didominasi oleh perdagangan (ILO dalam Widyaningrum, 2009).

Fokus dari penelitian ini sendiri adalah tentang Pedagang Kaki Lima (PKL) dan keberadaannya di ruang kota. Terlepas dari peran perdagangan informal dalam ekonomi perkotaan, keberadaan PKL di ruang publik seperti di tepi jalan umum, trotoar, taman, dan lapangan, dianggap sebagai masalah keruangan (Rachbini, 1994; Deguchi, 2005; Bhowmik, 2008), antara lain berupa penurunan fungsi dan kualitas fisik lingkungan serta penurunan kualitas visual ruang (Yatmo, 2008). Konflik ini yang mendorong pemerintah melakukan penertiban dan pemindahan lokasi berdagang PKL. Akan tetapi, tindakan ini tidak menyelesaikan masalah karena PKL selalu kembali berdagang ke lokasi semula atau berpindah berdagang ke lokasi lain (Yatmo, 2005). Keberadaan PKL di ruang kota adalah merupakan aktivitas riil, dan dapat dikategorikan sebagai 'activity support' (aktivitas yang mendukung kegiatan utama di kawasan dimana aktivitas 
ini berada). Keberadaan 'activity support' di ruang publik justru menguatkan keberadaan ruang publik sebagai ruang tempat interaksi masyarakat kota (Shirvani,1986). Sebagai aktivitas, 'activity support' akan cenderung berlokasi dalam suatu tempat yang sesuai dengan persyaratan aktivitasnya. Sehingga PKL pun yang juga dikategorikan sebagai 'activity support' di ruang perkotaan juga akan cenderung berlokasi dalam suatu tempat yang sesuai dengan karakteristik aktivitasnya (Shirvani, 1986). Dengan dasar pertimbangan bahwa PKL sebagai aktivitas adalah juga merupakan 'element of urban physical form', maka perlu dikenali lokasi ruangnya yang sesuai dengan karakteristik aktivitasnya (Shirvani, 1986; Cresswell, 1996; Yatmo, 2008). Kesimpulan ini juga berdasarkan pertimbangan bahwa aktivitas PKL di perkotaan tidak dapat diabaikan, sebab jika aktivitas ini diabaikan/ditiadakan berarti mematikan para pedagang jalanan yang berarti mematikan sumber nafkah kaum informal, dan jika jalanan di kota-kota besar dianggap sebagai tempat beraktivitas, maka daya kreativitas ini perlu difasilitasi dan bukannya dimatikan (Chapman dalam Rachbini, 1994). Selain itu tujuan memasuki PKL untuk mendapatkan kesempatan kerja dan memperoleh pendapatan, daripada memperoleh keuntungan (Sethuraman, 1991). Fasilitas tersebut dapat dilakukan melalui penyediaan ruang di perkotaan, yang secara konseptual terdiri atas ruang terbuka (square) dan ruang sirkulasi (street). Square mengemban fungsi sebagai ruang berkumpul aktivitas masyarakat kota. Ruang sirkulasi berfungsi sebagai ruang penghubung antar settlement dan penghubung settlement dengan square (Krier, 1975).

\section{Metode Penelitian}

Metodologi yang digunakan dalam melakukan kajian permasalahan lokasi PKL dalam dalam ruang perkotaan menggunakan metode literatur review. Dengan adanya metode ini, dapat menemukenali kekurangan/kelemahan teori sektor informal dan teori ruang terhadap penentuan lokasi PKL di ruang perkotaan.

\section{Permasalahan Lokasi PKL dalam Konsep Sektor Informal Pedagang Kaki Lima (PKL)}

Pembahasan mengenai penyediaan ruang di perkotaan bagi PKL menjadi penting karena pembahasan dan kajian PKL yang selama ini dilakukan terfokus pada perspektif ekonomi, sosial, kebijakan (Yustika, 2000; Sarjono, 2005), karakteristik perdagangan dan fisik, (Mc.Gee dan Yeung, 1977; Widjajanti, 2000; Pinandita, 2001; Yatmo, 2008), seperti diuraikan berikut ini. Dalam kajian yang berperspektif ekonomi, keberadaan PKL di negara-negara berkembang menurut Mc.Gee (1991) termasuk dalam perekonomian bazaar yang merupakan sektor yang memerlukan padat karya, dengan penggunaan tenaga kerja keluarga.

Selain itu, Hart (1991) menjelaskan pula PKL sebagai bagian dari sektor informal dalam kesempatan memperoleh pendapatan diperoleh dari usaha sendiri. Kesempatan memperoleh penghasilan di kota dari kegiatan informal dibedakan dalam dua tipologi yaitu sektor informal yang sah (legal) dan sektor informal tidak sah (illegal). Penghasilan informal yang legal diperoleh dari kegiatan primer, sekunder, tersier dengan modal relatif besar, distribusi kecil-kecilan (termasuk pedagang kaki lima), jasa, transaksi pribadi. Penghasilan informal illegal diperoleh dari aktivitas yang melanggar hukum, antara lain berupa kegiatan jasa barang curian, lintah darat, perdagangan obat bius, penyelundupan, penyuapan, perlindungan kejahatan, dan kegiatan transaksi pencurian kecil/pencopetan, pencurian besar/perampokan, pemalsuan uang, penipuan, perjudian.

Di tataran konseptual, terdapat perdebatan mengenai sektor informal dan usaha kecil. Sethuraman (1991) berpendapat bahwa PKL dalam sektor informal memiliki kekhasan yang berbeda dengan ekonomi skala kecil dan usaha skala kecil. Istilah sektor informal termasuk PKL biasanya digunakan untuk merujuk pada kegiatan ekonomi berskala kecil, tetapi akan menyesatkan bila disebut dengan usaha berskala kecil. Alasannya adalah sektor informal termasuk PKL merupakan manifestasi dari keadaan pertumbuhan kesempatan kerja di negara berkembang. Tujuan memasuki usaha kecil ini untuk mendapatkan kesempatan kerja dan memperoleh pendapatan, daripada memperoleh keuntungan. Berbeda halnya dengan Vacin (2007) yang mengatakan bahwa sektor informal dapat disebut sebagai usaha skala kecil. Usaha skala kecil memberikan keuntungan langsung dan keuntuingan tidak langsung kepada 
pemerintah/swasta dan penduduk kota. Keberadaan sektor informal terbukti dapat menekan rendahnya upah di institusi pemerintah dan swasta, solusi untuk masalah pengangguran, perubahan penghasilan pajak dan regulasi pemerintah, serta alat kontrol dalam menjaga harga pangan tetap rendah.

Dari sudut pandang sosial, PKL dalam sektor informal juga berperan mengurangi jumlah pengangguran (de Soto, 1992; Rachbini,1994), berfungsi juga sebagai katup pengaman dari ketidak mampuan sektor formal menyerap tenaga kerja tersebut (Rachbini, 1994) dan berfungsi sebagai alternatif dalam mengurangi jumlah pengangguran (de Soto, 1992; Rachbini,1994). Peran PKL mengurangi pengangguran terjelaskan melalui kajian di kota Lima (Peru) yang menunjukkan adanya pertumbuhan rata-rata pedagang jalanan sebesar $4,6 \%$ per tahun. Penyebab tumbuh dan berkembangnya perdagangan informal (PKL) antara lain dipengaruhi oleh migrasi dan pemutusan hubungan kerja (Sethuraman, 1991; de Soto, 1992; Rachbini, 1994, Sarjono, 2005; Alisjahbana, 2006). Selain itu dijelaskan juga bahwa sektor informal berperan melayani kebutuhan masyarakat kelas menengah ke bawah (Rachbini, 1994, de Soto, 1992), meningkatkan taraf hidup pelaku perdagangan informal (Sethuraman, 1991; de Soto, 1992; Rachbini, 1994). Kajian ILO di kota Lima menemukan bahwa pekerja di sektor informal dapat memperoleh pendapatan rata-rata 38\% lebih tinggi dari upah minimum (de Soto, 1992).

Selain berperan mengatasi pengangguran, dengan bekerja sebagai PKL, terjadi transformasi sosial ditingkat individu dan kelompok. Perubahan terlihat pada karakter peran yang dilakukan, interaksi yang timbul dari aktualisasi peran sosial dan jaringan sosial yang terbentuk (Mustafa, 2008). Transformasi sosial secara individu, menimbulkan sikap penghargaan masyarakat kepada individu, karena individu tersebut tidak berstatus pengangguran.

Kajian yang bernuansa kebijakan membahas kaitan antara PKL dan perlawanan terhadap kebijakan pemerintah, terutama dikaitkan dengan keberadaan PKL. Dalam posisinya sebagai kelompok marjinal, reaksi PKL, terhadap kebijakan penggusuran dilakukan melalui perlawanan, meliputi proses, modus, pendorong dan dampak (Alisjahbana, 2006). Proses perlawanan dilakukan melalui tahap membangun gerakan, membangun kesadaran kolektif, membentuk organisasi gerakan, upaya kebulatan tekad melakukan perlawanan, sampai melakukan gerakan perlawanan secara riil. Modus perlawanan dilakukan dengan cara terbuka dan dengan cara tersembunyi. Situasi yang mendorong perlawanan PKL terhadap pemerintah antara lain kebijakan penataan yang berpengaruh pada penurunan tingkat pendapatan PKL dan hilangnya kesempatan bagi masyarakat untuk mendapatkan barang kebutuhan sehari-hari dengan harga murah. Bagi pemerintah penataan hanya menciptakan ketertiban sementara. Sebagai dampak dari perlawanan yang dilakukan, PKL dapat terus berdagang, namun di sisi lain pemerintah semakin gencar melakukan penertiban. Masyarakat sendiri ada yang bersikap sinis terhadap PKL, dan ada pula yang tetap memanfaatkan keberadaan PKL untuk memenuhi kebutuhan dengan harga murah. Sikap pemerintah ini tidak lantas mematikan kehidupan PKL, melainkan justru menambah semangat mereka untuk bertahan. Timbulnya perlawanan PKL terhadap kebijakan pemerintah ini, pada prinsipnya hanya untuk menpertahankan hak hidupnya, yaitu hak untuk bekerja dan memperoleh penghasilan (Yustika, 2000).

Uraian yang disampaikan di atas menunjukkan bahwa kajian mengenai PKL yang selama ini dilakukan belum menyentuh isu ruang. PKL merupakan salah satu jenis sektor informal yang berlokasi di ruang-ruang kota, namun justru pembahasan mengenai ruang ini masih sangat terbatas. Sementara ini, studi mengenai karakteristik PKL menunjukkan bahwa jenis kegiatan ini membutuhkan ruang dalam pengertian tempat atau lokasi dan waktu. Berdasarkan kajian empiris mengenai PKL (street vendors), kegiatan ini dapat dikelompokkan berdasarkan: (a) Jenis sarana dagangan (gerobak,gerobak tenda, kios, gelaran,meja,pikulan), (b) waktu berdagang (mengikuti waktu aktivitas kegiatan utama kawasan), (c) sifat layanan (menetap/permanen, semi menetap/semi permanen, keliling/mobile), (d) Pola pelayanan/pola persebaran (aglomerasi, fokus aglomerasi) (McGee,T.G., dan Yeung,Y.M., 1977; Lintang, 2006; Dian, 2006; Wijayanti, 2006).

Karakteristik PKL seperti yang ditunjukkan di atas semakin menegaskan pentingnya kajian yang mengkaitkan PKL dan ruang, tepatnya lokasi kegiatan PKL. Sejauh ini, kajian mengenai PKL dan ruang difokuskan pada karakteristik aktivitas PKL, kebutuhan dan ukuran ruang, tata massa 
bangunan PKL di ruang publik, tampilan bangunan PKL, dan panduan rancang kota (urban design guideline), yang meliputi aspek 'building and massing', visual, estetika, 'open space', sirkulasi pejalan (Widjajanti, 2000; Pinandita, 2001; Yatmo, 2008). Pembahasan tersebut belum dapat menjawab pemilihan lokasi kegiatan PKL.

Selain itu, teori-teori yang terkait dengan penentuan lokasi (teori lokasi) tidak membahas mengenai lokasi PKL. Oleh karena itu, penelitian ini bermaksud mengisi kekosongan teoritis mengenai pemilihan lokasi kegiatan PKL melalui pendekatan perilaku.

Merujuk dari pembahasan pemetaan penelitian tentang pedagang kaki lima yang telah dilakukan, maka pembahasan dapat dikelompokan menjadi: a). kelompok sosial, b). kelompok ekonomi, c). Kebijakan, d). fisik/ruang, yang dapat dijelaskan sebagai berikut:

a. Kelompok sosial, pengelompokan ini didasarkan pada penelitian-penelitian yang membahas bahwa sektor informal/PKL merupakan salah satu alternatif untuk mendapatkan matapencaharian, sehingga dapat mengurangi pengangguran. Dengan bekerja sebagai PKL, mereka memperoleh penghasilan yang dapat meningkatkan taraf hidupnya (de Soto, 1989). Selain itu penelitian juga menjelaskan bahwa segi-segi sosial dan budaya (etnis, pendidikan, usia, asal daerah) melandasi seseorang terjun ke dalam PKL, sedangkan motivasi individu seperti kerja keras dan hemat sebagai orientasi terhadap keberhasilan kerja seseorang sebagai PKL (Nadjib, 1995). Sementara itu etos kerja seorang PKL dipengaruhi oleh semangat kerja (diukur dari waktu usaha/jam kerja, kerja keras, jujur, hemat, menghargai waktu), dan tingkat ketabahan dan keuletan PKL dalam berusaha (Firmansyah, 1995). Sedangkan tingkat pendidikan, tingkat penghasilan, dan usia mempengaruhi sikap PKL terhadap kepedulian kebersihan lingkungan berdagang (Susanto, 1995). Sementara itu seseorang berusaha sebagai PKL, menimbulkan perubahan status sosialnya, karena berusaha sebagai PKL untuk tercapai kesejahteraan sosial dan ekonomi. Untuk mencapai kesejahteraan ini dilandasi pada motif untuk memenuhi kebutuhan manusia (sandang, pangan, papan) secara layak yang kemudian meningkat untuk memenuhi keamanan dan kenyamanan hidup, sehingga status sosialnya meningkat dalam kehidupan (Mustafa, 2008). Merujuk pada pokok-pokok bahasan penelitianpenelitian ini, maka fokus penelitian ini adalah pada aspek-aspek sosial.

b. Kelompok ekonomi, penelitian-penelitian membahas berdasarkan pada aspek-aspek ekonomi, sebagai berikut: karakteristik perdagangan PKL yang meliputi jenis dagangan, jenis sarana dagangan, waktu berdagang, pendapatan usaha PKL, pola sebaran PKL, pola konsentrasi PKL. Karakterisitik pelaku PKL (usia, pendidikan, lama berjualan, etnik dan asal daerah mempengaruhi jenis dagangan PKL) (Deguchi, 2008; Hugo, 1991; McGee dan Yeung, 1977). Dijelaskan pula keterkaitan sektor informal dengan sektor formal dalam aktivitas perdagangan (penyediaan barang dan jasa murah bagi sektor formal, menyediakan kebutuhan dan pelayanan bagi masyarakat berpenghasilan rendah, sektor informal sebagai sumber pertumbuhan ekonomi) (Tokman, 1979; Chandrakirana, 1994). Fobes (1983) menjelaskan struktur perdagangan sektor informal berdasarkan tiga kategorisasi pedagang (penjual borongan, pengecer besar, pengecer kecil). Sedangkan Bromley (1983) menjelaskan hubungan antara pedagang kaki lima dengan penyalur bahan/komoditi dagangan (penjualan atas komisi, dan pekerjaan yang tergantung: PKL dalam usahanya mendapatkan pinjaman modal dari pengusaha besar), dan politik berdagang (para PKL menjual barang dengan harga lebih rendah dari harga toko/supermarket). Selain itu juga dijelaskan oleh de Soto (1989) dan Astuty (1995) bahwa retribusi dari PKL meningkatkan pemasukan pajak bagi pemerintah. Penelitian juga membahas struktur pasar PKL yang merujuk pada persaingan sempurna, persaingan monopolistik, oligopoli, monopoli. Disisi lain membahas pula cara PKL memasarkan produk dan meningkatkan usaha (cara menetapkan harga, cara membayar pembelian produk) (Hamid, 1995). Sedangkan tingkat keberhasilan PKL dalam usahanya tergantung pada keberhasilan strategi marketing (produk, harga, penempatan, promosi) (Soen'an, 1995). Selain itu pola kegiatan (lokasi usaha, pengadaan/pasokan barang, cara pengelolaan usaha), akses terhadap pasar (barang yang diperdagangkan dan bentuk persaingan, omset, jangkauan pasar), mempengaruhi tingkat pendapatan PKL (Sukesi, 1995).

c. Kelompok Kebijakan, penelitian yang membahas tentang model yang diperlukan dalam pengembangan PKL yang menjelaskan bahwa pembentukan usaha diserahkan kepada PKL, 
sedangkan pihak swasta dan pemerintah daerah berperan sebagai motivator terciptanya peningkatan usaha PKL. Selain itu kebijakan makro berupa pengakuan dan perlindungan pemerintah daerah terhadap PKL dan kebijakan mikro berupa peningkatan efisiensi ekonomi usaha PKL, peningkatan produksi usaha PKL, pengupayaan usaha PKL yang kurang potensial menjadi usaha yang lebih potensial (Firdausy, 1995). Dijelaskan pula implementasi kebijakan penertiban PKL di perkotaan dengan analisis kebijakan publik untuk menemukan tingkat keberhasilan implementasi penanganan masalah kaki lima (Kurniadi dan Hessel, 2001). Selain itu Sarjono (2005) menjelaskan tentang pemahaman formalisasi PKL oleh pemerintah daerah, pemahaman formalisasi oleh PKL, dan pemahaman formalisasi menurut pemilik/pengusaha toko swalayan, formalisasi menurut pemahaman konsumen yang menjadi pertimbangan dalam kebijakan penataan dan formalisasi PKL. Bhowmik (2005) juga menjelaskan bahwa kebijakan penertiban PKL dengan memberikan perlindungan kepada PKL dengan memberi lisensi dan fasilitas kredit, dibentuk manajemen perdagangan bagi PKL oleh pemerintah, dalam dokumen perencanaan kota ditetapkan ruang untuk PKL. Demikian pula penjelasan Bettcher (2009) kebijakan penertiban PKL di kota Lima Colombia, dengan formalisasi PKL berupa pemberian ijin operasional. Sementara itu Alisjahbana (2006) menjelaskan modus perlawanan (perlawanan terbuka, perlawanan terselubung, perlawanan normatif) dan dampak perlawanan PKL (dampak penataan, dampak perlawanan) terhadap penerapan kebijakasanaan penataan oleh pemerintah.

Kelompok fisik/ruang, penelitian-penelitian yang menjelaskan penataan PKL di ruang publik. Pada penelitian penataan PKL di ruang publik dijelaskan aspek-aspek penataan berdasarkan pada karakteristik aktivitas PKL (karakteristik perdagangan, karakteristik pedagang, karakteristik konsumen), kebutuhan dan ukuran ruang, penataan tiga dimensi ruang, visual dan estetika kawasan, panduan rancang kota (Widjajanti, 2000; Pinandita, 2001). Penelitian Surya (2006), Hariyani (2006), dan Dwijayanti (2006) menjelaskan identifikasi karateristik perdagangan PKL, karakteristik pedagang, karakteristik konsumen, pola persebaran PKL, dan pola layanan PKL di ruang publik. Sedangkan Yatmo (2008) menjelaskan bahwa PKL sebagai elemen pembentuk ruang kota, keberadaannya di ruang kota merupakan elemen out of place, sehingga menimbulkan permasalahan ruang dan visual kawasan. Namun dijelaskan pula permasalahan ini dapat diatasi dengan penataan fisik dan penataan tampilan/estetika arsitektural.

Lihat tabel 1.1. peta penelitian tentang pedagang kaki lima.

Tabel 1.1. Peta Penelitian Tentang Pedagang Kaki Lima

\begin{tabular}{|c|c|c|c|c|}
\hline Tahun & SOSIAL & EKONOMI & KEBIJAKAN & FISIK/RUANG \\
\hline 1977 & & $\begin{array}{lr}\text { T.G. McGee } & \text { dan Y.M. } \\
\text { Yeung } & (1977): \\
\text { Karakteristik } & \text { prdagangan } \\
\text { dan } & \text { karakteristik } \\
\text { pedagang. } & \\
\text { Lokasi: Manila, Jakarta, } \\
\text { Kualalumpur }\end{array}$ & & \\
\hline 1979 & & $\begin{array}{l}\text { Victor E.Tokman (1979): } \\
\text { Kompetisi antara sektor } \\
\text { informal dan sektor formal } \\
\text { dalam perdagangan } \\
\text { eceran. Lokasi: Santiago }\end{array}$ & & \\
\hline 1983 & & \begin{tabular}{lrr} 
Dean & Forbes & $(1983):$ \\
Struktur & perdagangan. \\
Lokasi: Ujung & Pandang \\
Ray Bromley & (1983): \\
Organisasi, Peraturan, dan \\
Pengusahaan PKL. Lokasi: \\
\multicolumn{2}{l}{ Cali, Colombia }
\end{tabular} & & \\
\hline 1989 & $\begin{array}{lcr}\text { Hernando } & \text { de } & \text { Soto } \\
\text { (1989): } & \text { Mengurangi } \\
\text { penganguran, } & \\
\end{array}$ & $\begin{array}{l}\text { Hernando de Soto (1989): } \\
\text { Meningkatkan pemasukan } \\
\text { pajak bagi Pemerintah. }\end{array}$ & & \\
\hline
\end{tabular}




\begin{tabular}{|c|c|c|c|c|}
\hline Tahun & SOSIAL & EKONOMI & KEBIJAKAN & FISIK/RUANG \\
\hline & $\begin{array}{l}\text { Meningkatkan taraf } \\
\text { hidup PKL }\end{array}$ & Lokasi : Lima, Colombia & & \\
\hline 1994 & & $\begin{array}{l}\text { Kamala Chandrakirana } \\
\text { dan Isono Sadoko (1994): } \\
\text { Dinamika hubungan dalam } \\
\text { jaringan usaha PKL. } \\
\text { Lokasi: Jakarta }\end{array}$ & & \\
\hline 1995 & 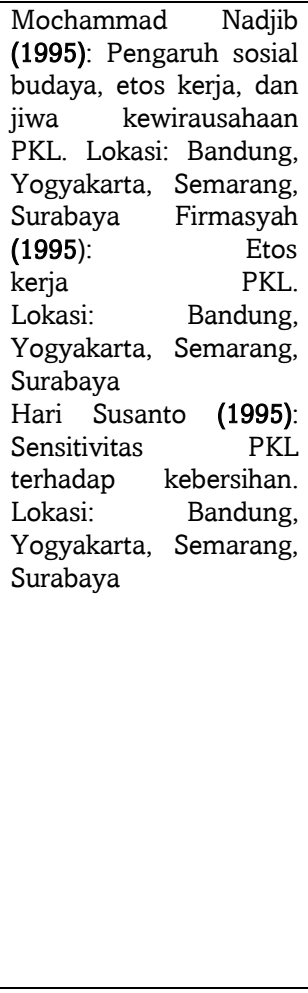 & 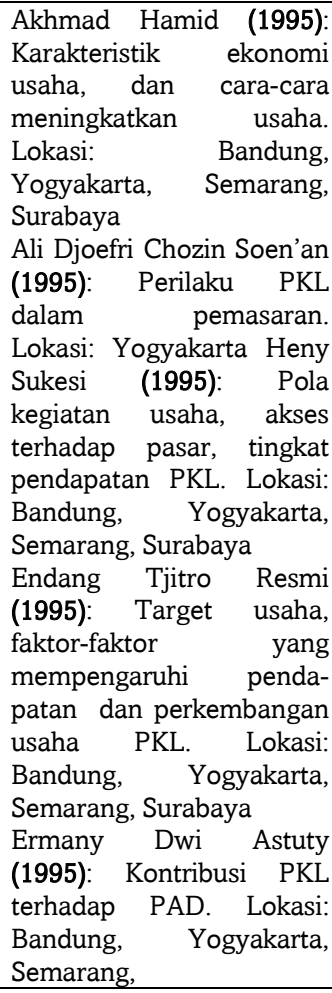 & $\begin{array}{lr}\text { Caruni Mulya } & \text { Firdausy } \\
\text { (1995): } & \text { Model } \\
\text { dan } & \text { kebijakan } \\
\text { pengembangan } & \text { PKL. } \\
\text { Lokasi: } & \text { Bandung, } \\
\text { Yogyakarta, } & \text { Semarang, } \\
\text { Surabaya } & \end{array}$ & \\
\hline 2000 & & 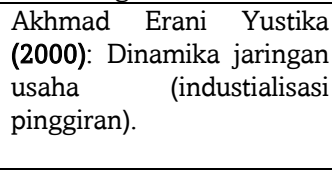 & & $\begin{array}{l}\text { Retno Widjajanti (2000): } \\
\text { Penataan fisik PKL } \\
\text { (Panduan Rancang Kota) } \\
\text { pada kawasan komersial. } \\
\text { Lokasi: Semarang } \\
\end{array}$ \\
\hline 2001 & & & $\begin{array}{lr}\text { Tri Kurniadi, Sh.,Msi.; dan } \\
\text { Drs. Hessel } & \text { N.ST., M.Si. } \\
\text { (2001): } & \text { Kebijakan } \\
\text { Penertiban } & \text { PKL. } \\
\text { Lokasi: Jakarta } & \\
\end{array}$ & $\begin{array}{l}\text { Ivan Pinandita (2001): } \\
\text { Penataan PKL di Alun- } \\
\text { alun. Lokasi: Garut }\end{array}$ \\
\hline 2005 & & & $\begin{array}{l}\text { Dr. Yetty Sarjono, M.Si. } \\
\text { (2005): } \\
\text { Penataan dan formalisasi } \\
\text { PKL kerjasama } \\
\text { pemerintah kota dengan } \\
\text { pengusaha toko swalayan. } \\
\text { Lokasi: Surakarta } \\
\text { Sharit K. Bhowmik (2005): } \\
\text { Kebijakan Penertiban PKL. } \\
\text { Lokasi: Thailand, } \\
\text { Singapura, Malaysia, } \\
\text { Filipina, dan Korea }\end{array}$ & \\
\hline 2006 & & & $\begin{array}{l}\text { Dr.Ir. Alisjahbana, MA } \\
\text { (2006): } \\
\text { Perlawanan PKL terhadap } \\
\text { kebijakan penataan. } \\
\text { Lokasi: Surabaya }\end{array}$ & 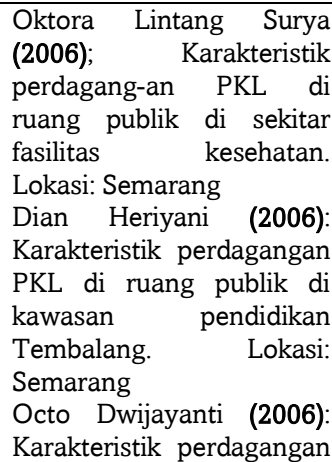 \\
\hline
\end{tabular}




\begin{tabular}{|l|l|l|l|l|}
\hline Tahun & SOSIAL & EKONOMI & KEBIJAKAN & \multicolumn{1}{c|}{ FISIK/RUANG } \\
\hline 2008 & $\begin{array}{l}\text { Dr. Ali Achsan Mustafa } \\
\text { (2008): } \\
\text { Transformasi sosial PKL } \\
\text { pada individu maupun } \\
\text { kelompok. } \\
\text { Lokasi: Surabaya }\end{array}$ & & $\begin{array}{l}\text { PKL di ruang publik di } \\
\text { kawasan perdagangan. } \\
\text { Lokasi: Semarang }\end{array}$ \\
\hline 2009 & & $\begin{array}{l}\text { Yandi Andri Yatmo (2008): } \\
\text { PKL sebagai 'out of place } \\
\text { element perkotaan. } \\
\text { Lokasi: Jakarta }\end{array}$ \\
\hline
\end{tabular}

Sumber: Widjajanti, 2013

\section{Permasalahan Lokasi PKL dalam Teori Lokasi}

Tumbuh dan berkembangnya PKL di perkotaan, sering dianggap menimbulkan penurunan fungsi ruang-ruang publik kota. Dalam hal ini khususnya, pertumbuhan dan perkembangan PKL yang berlokasi di ruang terbuka (square) dan ruang sirkulasi (street) di perkotaan telah mengubah fungsi ruang-ruang tersebut, sehingga tidak sesuai lagi dengan fungsi sebenarnya, serta menurunkan kualitas lingkungan dan visual kawasan. Ketidaksesuaian dan penurunan fungsi ruang tersebut menimbulkan konflik pemanfaatan ruang.

PKL merupakan aktivitas di ruang kota, memerlukan ruang sebagai lokasi tempat aktivitasnya yang sesuai dengan persyaratan aktivitasnya yang terkait dengan pengguna (pelaku PKL dan konsumen) dan aktivitas itu sendiri (karakteristik aktivitas perdagangan PKL) (Shirvani, 1986; Watson,Platus dan Shibley, 2003). PKL sebagai aktivitas sektor informal di bidang perdagangan dan jasa di ruang kota, beraktivitas di ruang-ruang publik kota. Aktivitas PKL tumbuh dan berkembang di ruang perkotaan karena adanya pengaruh aktivitas utama di kawasan dimana PKL itu berada (Yudo, 1995; Mc.Gee dan Yeung, 1977). Keberadaannya di ruang publik merupakan salah satu bentuk aktivitas yang dapat dikategorikan sebagai "activity support', aktivitas PKL bersama-sama dengan aktivitas lainnya memperkuat fungsi ruang publik kota (Shirvani, 1986; Watson, Plattus dan Shibley, 2003). Disamping itu aktivitas merupakan salah satu elemen pembentuk fisik ruang kota akan saling melengkapi saling mempengarruhi (Shirvani, 1986). Namun bila aktivitas-aktivitas tidak diatur susunan ruang aktivitasnya akan selalu menimbulkan konflik ruang. Sementara itu keberadaan PKL sebagai aktivitas di ruang kota dianggap sebagai elemen pengganggu atau unplaned element atau out of place, sering menimbulkan ketidakserasian tatanan fisik dan estetika visual lingkungan (Hough, 1990; Creswell, 1996; Yatmo, 2008). Sedangkan menurut para designer, elemen pengganggu ini perlu ditiadakan. Namun disisi lain, keberadaan PKL dapat dipandang sebagai "in place element" dengan memahami konteks keberadaannya di suatu lokasi dan mempertimbangan potensi PKL sebagai identitas lokal suatu tempat, sehingga sangat penting mengenali konteks keberadaan PKL ini dalam perencanaan kota, yang dapat menjadi pertimbangan dalam penentuan kebijakan penertiban dan penggusuran PKL (Yatmo, 2008). Selain itu dengan meniadakan aktivitas PKL sama saja dengan menutup kesempatan manusia untuk mendapatkan penghasilan sebagai upaya untuk membertahankan hidup (Chapman dalam Rachbini, 1994).

Adapun pada perkembangan saat ini pendekatan ruang di perkotaan mengacu trialectic yaitu pada ruang itu sendiri, kesejarahan, dan sosial (Lefebvre, 1998; Soja, 2004). PKL tumbuh dan berkembang di ruang perkotaan akibat kondisi sosial ekonomi di perkotaan, dan kesejarahan aktivitasnya, sehingga keberadaan aktivitas PKL di ruang perkotaan menjadi aktivitas yang perlu diakomodasi di dalam ruang. Dengan mengakomodasi aktivitas PKL dan juga sebagai aktivitas riil di ruang perkotaan, selalu membutuhkan lokasi sebagai tempatnya beraktivitas (Shirvani, 1986). Merujuk dari beberapa pendapat yang dapat mendukung keberadaan aktivitas PKL di ruang kota, maka penting mengenali lokasi yang sesuai dengan karakternya. 
Kajian yang secara khusus menjelaskan konsep lokasi PKL belum tersedia. Di sisi lain, terdapat teori lokasi untuk retail (perdagangan eceran) yang membahas penentuan lokasi retail pada ruang dengan status kepemilikan dan hak kepemilikannya terlindungi oleh hukum (Jones dan Simmons, 1993). Adapun aktivitas perdagangan PKL merupakan usaha kecil yang memiliki kesamaan karakteristik dengan kegiatan retail, yang membedakan adalah PKL beraktivitas di ruang publik yang status kepemilikan dan hak kepemilikannya tidak terlindungi oleh hukum (Bromley, 1979; de Soto, 1992; ILO-URDI, 2005; Bhowmik, 2008), dimana PKL beraktivitas bersama-sama dengan aktivitas lainnya. Kegiatan retail seperti PKL ini sangat sedikit jika ada penelitian yang membahas di dalam teori lokasi retail. Mengingat pentingnya peran PKL dalam mengatasi ketersediaan lapangan pekerjaan dan dalam perdagangan informal, serta keberadaannya merupakan aktivitas riil di ruang perkotaan (Todaro, 2000; ILO dalam Todaro, 2000), maka penting ditambahkan konsep lokasi PKL dalam teori lokasi retail, sehingga dapat dikenali dan diketahui lokasi yang tepat untuk PKL sesuai dengan karakteristik aktivitasnya.

Lihat gambar 1.2. Permasalahan Penelitian Penentuan Lokasi PKL di Ruang Kota

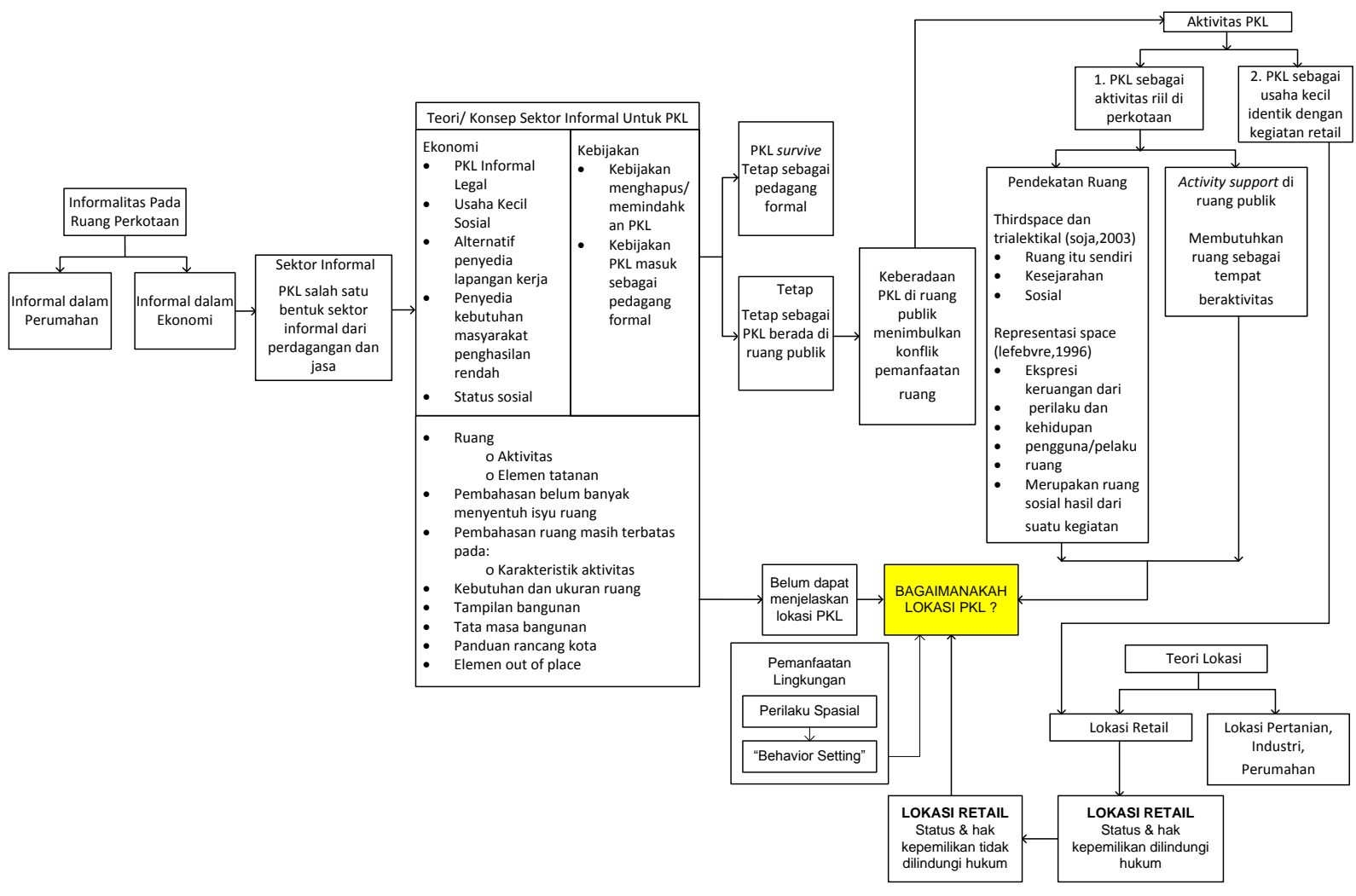

Sumber: Widjajanti, 2013

Gambar 1.2 PERMASALAHAN PENELITIAN

\section{Kesimpulan}

Kesimpulan dari kajian permasalahan lokasi pedagang kaki lima (PKL) dalam ruang perkotaan, yaitu bahwa permasalahan lokasi PKL dalam konsep PKL, hingga saat ini belum terbahas karena lebih kepada bidang ekonomi, sosial dan kebijakan. PKL merupakan salah satu jenis sektor informal yang berlokasi di ruang-ruang kota, namun justru pembahasan mengenai 
ruang ini masih sangat terbatas. Kajian mengenai PKL yang selama ini dilakukan belum menyentuh isu ruang. Sementara ini, pembahasan PKL lebih mengkaji dari sisi jenis aktivitas, kebutuhan ruang, penataan fisik dan penataan tampilan/estetika arsitektural.

Selain itu, teori-teori yang terkait dengan penentuan lokasi (teori lokasi) tidak membahas mengenai lokasi PKL. Oleh karena itu, penelitian ini bermaksud mengisi kekosongan teoritis mengenai pemilihan lokasi kegiatan PKL melalui pendekatan perilaku ruang.

Kajian yang secara khusus menjelaskan konsep lokasi PKL belum tersedia. Di sisi lain, terdapat teori lokasi untuk retail (perdagangan eceran) yang membahas penentuan lokasi retail pada ruang dengan status kepemilikan dan hak kepemilikannya terlindungi oleh hukum. Namun, kegiatan retail seperti PKL ini sangat sedikit jika ada penelitian yang membahas di dalam teori lokasi retail, maka penting ditambahkan konsep lokasi PKL dalam teori lokasi retail, sehingga dapat dikenali dan diketahui lokasi yang tepat untuk PKL sesuai dengan karakteristik aktivitasnya.

\section{Ucapan Terima Kasih}

Ucapan terimakasih kepada Arief Rosyidi, Dr, M. Arch., MSP, Tubagus Furqon Sofhani, $\mathrm{PhD}$, MA, Ir dan Iwan Kustiwan, Dr, MT, Ir sebagai pembimbing program doktor yang telah memberi pengarahan sehingga berhasil disusunnya artikel ini.

\section{Daftar Pustaka}

Alisjahbana. 2006. Sisi Gelap Perkembangan Kota: Resistenci Sektor Informal Dalam Perspektif Sosiologis. Yogyakarta: Laksbang Pressindo.

Bhowmik S.K. 2008. Street Vendors In Asia : A Review. (Paper)

Bromley, R. 1979. Introduction-The Urban Informal Sector. Why is it Worth Discussing? The Urban Informal Sector : Critical Perspectives on Employment and Housing Policies. Oxford : Pergamon Press.

Chandrakirana, Kamala, dan Isono Sadoko. 1994. Dinamika Ekonomi Informal di Jakarta. UI-Press.

Creswell, John W. 1996. Research design: Qualitative, Quantitative, and Mixed Methods Approaches. SAGE

De Soto, Hernando. 1992. Masih Ada Jalan Lain (Revolusi Tersembunyi di Negara Ketiga). Jakarta Yayasan: Obor Indonesia

Deguchi A. 2005. Re-Evaluating Street Vendors In Asian Cities and Urbanism. Makalah pada 8th International Conferenence of The Asian Planning Schools Association.

Firmansyah. 1995. Etos kerja PKL. Lokasi: Bandung, Yogyakarta, Semarang, Surabaya

Hamid, Akhmad. 1995. Karakteristik Ekonomi Usaha, dan Cara-Cara Meningkatkan Usaha. Lokasi: Bandung, Yogyakarta, Semarang, Surabaya

Hart, Keith. 1985. Sektor Informal, Urbanisasi, Pengangguran dan Sektor Informal di Kota. Penyunting Chriss Manning dan Tadjuddin Noer Effendi. Jakarta: PT Gramedia: 78.-108

Heryani, Dian. 2006. Penataan Fisik Kegiatan Pedagang Kaki Lima Pada Kawasan Komersial Di Pusat Kota (Studi Kasus : Simpanglima Semarang).

Krier, Rob. 1975. Architectural Composition, dalam versi bahasa Indonesia diterjemahkan oleh Ir. Effendi Setiadharma, dkk. Penerbit Erlangga. Jakarta

Lefebvre, Henri. 1998. The Production of Space. Massachusetts: Basil Backwell, Inc.

McGee, T.G. dan Y.M. Yeung. 1977. Hawkers in Southeast Asian Cities: Planning for The Bazaar Economy. Ottawa: International Development Research Centre.

Mustafa, Ali Achsan. 2008. Transformasi Sosial PKL Pada Individu Maupun Kelompok. Lokasi: Surabaya

Nadjib, Mochammad . 1995. Pengaruh Sosial Budaya, Etos Kerja, dan Jiwa Kewirausahaan PKL. Lokasi: Bandung, Yogyakarta, Semarang, Surabaya

Rachbini, Didik J. 1994. Ekonomi Informal Perkotaan. LP3ES Jakarta.

Dwijayanti, Oktarina. 2006. Kajian Karakteristik Berlokasi Pedagang Kaki Lima ( PKL ) di Kawasan Pendidikan Tembalang Kota.

Surya, Oktora Lintang. 2006. Penataan Fisik Kegiatan Pedagang Kaki Lima Pada Kawasan Komersial Di Pusat Kota (Studi Kasus : Simpanglima Semarang).

Pinandita, Ivan. 2001. Penataan PKL di Alun-alun. Lokasi: Garut 
Santoso. 2008. Pedagang Kaki Lima dan Informalitas Perkotaan. Jakarta Butuh Revolusi Budaya.

Sethuraman, S. V. 1991. Sektor Informal di Negara Sedang Berkembang. Urbanisasi, Pengangguran, dan Sektor Informal di Kota. (C. Manning \& T. N. Effendi). Jakarta : Yayasan Obor Indonesia.

Shirvani, Hamid. 1986. The Urban Design Process. New York: Van Nostrad Reinhold Company, Inc.

Jones, Ken and Jim Simmons. 1990. Location Location Location Analyzing The Retail Environment. Nelson, Canada

Soen'an, Ali Djoefri Chozin. 1995. Perilaku PKL Dalam Pemasaran. Lokasi: Yogyakarta

Soja, Edward W 2004. Postmodern Geographies : The Reassertion of Space in Critical Social Theory. Prentice-Hall

Sukesi, Heny. 1995. Pola kegiatan usaha, akses terhadap pasar, tingkat pendapatan PKL. Lokasi: Bandung, Yogyakarta, Semarang, Surabaya

Susanto, Hari. 1995. Sensitivitas PKL Terhadap Kebersihan. Lokasi: Bandung, Yogyakarta, Semarang, Surabaya

Todaro, Michael. 2000. Pembangunan Ekonomi. Jakarta. Bumi Aksara.

Watson, Donald., Alan Platus., dan Robert Shibley. 2003. Time Saver Standards for Urban Design. McGraw-Hill, New York.

Widjajanti, Retno. 2000. Penataan Fisik Kegiatan Pedagang Kaki Lima Pada Kawasan Komersial Di Pusat Kota (Studi Kasus : Simpanglima Semarang).

Yatmo, Yandi Andri. 2008. Street Vendors As Out Of Places Urban Element. Journal Of Urban Design, Vol. 13 No.3, 387-402, Octobre 2008.

Yustika, Ahmad Erani. 2000. Industrialisasi Pinggiran. Pustaka Pelajar, Yogyakarta 